International Journal of Instruction e-ISSN: 1308-1470 • www.e-iji.net

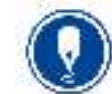

January $2021 \bullet$ Vol.14, No.1

p-ISSN: 1694-609X

pp. 121-142

Article submission code:

20191113041046
Received: 13/11/2019

Revision: 08/06/2020
Accepted: 29/06/2020

OnlineFirst:10/10/2020

\title{
The Development of Historical Thinking in Colombian Students: A Review of the Official Curriculum and the Saber 11 Test
}

\section{Nancy Palacios Mena}

Asst. Prof., University of the Andes, Colombia, n.palaciosm@uniandes.edu.co

The main objective of this article is to determine the level of development of historical thinking in the official curriculum and the Saber 11 Test in Colombia. The content of the training objectives of social sciences in primary and secondary schools, the Curricular Standards for this field, and the history questions of the Saber 11 Test of 2014, were analyzed. The data indicate that the intention to improve the traditional and rote teaching methods of history, defined in the training objectives and Curricular Standards of the social sciences field of study and published by the Colombian State, is not reflected in the evaluation carried out by the State itself with students who have finished secondary education. The requirements continue to be basic, and the results with the students show that even at these basic levels, no significant learning advances have been accomplished.

Keywords: historical thinking, evaluation, curriculum, history teaching, Saber 11 Test

\section{INTRODUCTION}

The main objective is to determine the level of development of historical thinking in the official curriculum and the Saber 11 Test. $^{1}$ By official curriculum, we understand the training objectives in the social sciences disciplines for primary and secondary education contemplated in the General Law of Education (Law 111 of 1994) and the Social Sciences Curricular Standards published by the MEN in 2004. ${ }^{3}$ The Saber 11 Test is the university entrance examination that students present at the end of secondary education. One of this test's components is an evaluation of social sciences and civic engagement competences in which history questions are included.

In accordance with Santisteban, González and Pagès (2010), we believe that this paper, besides contributing to the research of didactics in history, helps to ponder on research

\footnotetext{
${ }^{1}$ The results of the Saber 11 Test are one of the indicators to classify the Educational Institutions of Primary and Secondary Education. It is also considered as the main requirement for admission in the majority of the higher educational institutions of the country. The Saber 11 Test is designed and evaluated by the Colombian Institute for the Evaluation of Education (ICFES).

${ }^{2}$ In Colombia, the social sciences area includes history, geography, Political Constitution and democracy.

${ }^{3}$ According to the Ministry of Education (2004), the Curricular Standards constitute one of the parameters of what every child and teenager should know and do in order to achieve the expected quality level during the years spent in the educational system.
}

Citation: Palacios, N. (2021). The Development of Historical Thinking in Colombian Students: A Review of the Official Curriculum and the Saber 11 Test. International Journal of Instruction, 14(1), 121-142. https://doi.org/10.29333/iji.2021.1418a 
methods that may generate useful models to improve both teaching and training of teachers. The paper is specifically concerned with determining the existence of skills to develop historical thought in the primary and secondary social sciences curriculum and with comparing these findings with the results of the exam performed at the end of secondary school.

In consequence, the text includes three topics: a review of papers that have dealt with this topic in the last decades, an exposition of the skills required for the development of historical thought, identified in curricular materials designed by the Ministry of National Education (MEN) and in the evaluation of the Saber Test or entrance exam to the university, and a discussion and conclusions.

\section{Background and theoretical foundation}

\section{Development of historical thought: objectives and scope}

Although the training approach to historical thinking has been a long-standing commitment (Barton and Levtik, 2004), it is undeniable that in recent years, this interest has been revitalized and materialized thanks to researchers who deal with the teaching of history. The development of historical thought that has resulted in an important conceptualization is understood as a process that leads students to understand history and base investigations on history itself (Osborne, 2003; Seixas, 2011).

Historical thought can be defined as a set of skills of historical work that students may find useful to build knowledge in an autonomous way (Martineau, 1999; Wineburg 2001; Pagès, 2009), or as the meaning of the past through strategies that allow moving from basic levels of thoughts to much more elaborate ones (Lee and Ashby, 2000; Plá, 2005; Levesque, 2008; Santisteban, Pagès and González, 2010; Plá and Pérez, 2013). According to Santisteban (2010), "in order to think historically it is necessary to think in time, to move mentally in time, and to be aware of temporality so as to build a historical consciousness that relates the past with the present and that is aimed toward the future" (39)

Consequently, thinking historically requires learning the discipline through basic knowledge not only of history, but also about history, its concepts, methods, and rules used in relevant analyses and development (Wineburg, 2007; Seixas, 2011; Seixas and Morton, 2013; Van Sledright, 2004 and 2014a; Sáiz and López Facal, 2014; Gómez, Ortuño and Molina, 2014; coinciding with Éthier, Demers and Lefrançois, 2010). In this conceptualization, we can say that there are three elements to be highlighted: the importance of using historical methodological procedures, the development of comprehension skills, and the need for implementation and evidence of progression processes in student learning.

One of the main aspects in which didactics of history researchers agree is the need for the teaching of this discipline to advance from contents of the first order to those of the second order. The first order includes the traditional ones with dates and concepts; the second are strategic ones that organize those from the first order, and explain and relate them to the historians' work and ability to think historically (Gómez and Miralles, 2014; 
VanSledright, 2011; Barca, 2011; Clark, 2011; Sáiz and Gómez, 2016; Carretero and López, 2009; Domínguez, 2015; López et al, 2011, VanSledright and Limon, 2006; Prats and Santacana, 2011; Stearns, Seixas and Wineburg, 2000; Lee, 2005).

The development that research has had in historical thought formation in primary and secondary education has been strongly influenced by evolutionary psychology papers, sociocultural studies, philosophy, and by the epistemology of history (Fuster, 2017; Sáiz and López Facal, 2014). According to Éthier, Demers and Lefrançois (2010), progress in understanding what students learn or not in history class is largely due to curricular advances in which cognitive development, epistemology, didactics of social sciences, and more specifically of history, have been combined.

According to Domínguez (2015), the excellent dialogue between psychologists and professionals in didactics of history has been important in the progressive internationalization of research on the teaching of this discipline. "The two lines of research, didactics and psychology, corroborate the key role that methodological concepts have in the learning of historical thought" (48). The development of historical thought is opposed to a long tradition of teaching the discipline focused on the content (Pagès, 2010). Since teachers are not able to explore more profound levels of historical knowledge due to the urgency to comply with generally very extensive programs, the school experience is narrowed down to voicing and memorizing data, dates, historical figures and facts, with little or no connection. It implies teaching centered on chronology with finished, closed and linear discourses of historical events. (Fuster, 2015; Trigueros, Ortuno and Molina, 2014; Pousa and López, 2013).

Besides preventing historical knowledge from being more profound and complex, the traditional approach to teaching this discipline has had the following consequence: rather than using logical thought and its procedures, "students rely more on habitual ways of thinking and concepts of their daily life to explain and understand the past and the present than on interpretive concepts that emanate from history." Thus, knowledge about history has been relegated, and cognitive abilities of broad potential and coherence have been left with educational approaches such as basic educational competences (Pagès, 2010; Sáiz, 2013; Sáiz and López Facal, 2014).

The persistence of not very active methodologies, centered on students' interests and anchored in traditional models of teaching history, is due to two reasons, among others: First, to the tendency to use the discipline as an instrument of transmission of values and feelings of national identity. Despite attempts at renewal, a large number of curricula survive in which a vision of the teaching of progressive and linear history prevails, with exaltation of certain events and characters as protagonists (Carretero, 2007; Carretero et al, 2012; Trigueros, Ortuño and Molina, 2014; Morín, 2001).

Secondly, to the pedagogical and didactic proposals of history that have received a strong influence from the positivist perspective that conceives it as a descriptive and conceptual discipline, whose main purpose is to organize data from objective documents that possess the truth, and to transmit in the classrooms, facts that in many cases end up perpetuating exclusions and hegemonic ideologies (Gómez, Miralles and Molina, 2014; 
Granata and Barale, 2011). According to Sáiz and López Facal (2014), in order to change the traditional ways of teaching history, it is necessary to have learning processes that integrate knowledge of and about history, that guarantee that historical knowledge include complex cognitive skills, and that notions and concepts that transcend the memorization of dates, places and data be integrated into the classroom work.

In this same line of thought, Pellegrino, Chudowsky and Glacer (2001), Santisteban (2008 and 2010), Martineau (1999) and Pagès (2009) emphasize that the learning of history must go through teaching processes that integrate the pedagogical and cognitive foundations of the discipline with the way of reasoning, with its own procedures, concepts and interpretations, and with the incorporation of global and local perspectives that combine static and dynamic elements of change and continuity that seek relationships between the past, the present and the future.

\section{Development of historical thought and training for citizens}

One of the reasons for teaching social sciences is to promote civic engagement and participation, which is why the development of historical thought is one of the axes to achieve this goal. The process of acquiring historical consciousness is part of constructing a meaningful experience of time, based on the understanding of the past and present. This awareness is also an indispensable tool for citizens to exercise an enlightened participation in democracy (Rüsen, 2007; Martineau, 1999; Pagès, 2009; Souto, 2011 and Stearns 2000). According to these authors, the development of historical thought promotes active citizenship, prepares students to participate more consciously in social life, and goes beyond the patriotic feeling, involving daily actions such as the non-assimilation of everything transmitted by the media, the questioning of social, economic and political situations of the environment in which they live, the vindication of rights, and the rejection of phenomena such as corruption, exclusion and inequalities.

Educability is another important axis in the development of historical thought that can be acquired in school and through some adequate pedagogical and didactic strategies. Investigations of past decades in the field of didactics of social sciences in general, and of history in particular, have shown that this type of thinking is not natural and, therefore, a process of teaching and learning is required (Wineburg, 2001; Plá, 2003; Plá and Pérez, 2013; Lee and Ashby, 2000).

The studies of Pontecorvo and Girardet (1993) and Cooper and Capita (2004) have shown that when the concepts learned in the classrooms are fully understood and integrated to the social reality through investigative processes and when there are debates about students' interpretations, the development of historical thought is favored. The teacher's guidance is an important tool both in the conceptual construction as in the acquisition of investigative skills. All these authors defend the idea that the development of historical thought must be present in the learning activities and the evaluation of students. This implies that the teaching task cannot continue to reproduce methodologies that are not oriented to enhance skills that propitiate the construction of historical knowledge. 
Some of the difficulties that primary and secondary school students encounter in learning history have their origin in the training of teachers. They lack a proper education in processes of metacognition of historical knowledge that would allow them to abandon the relativist and positivist positions that still prevail. (VanSledright, 2014b). Saiz and López (2014) believe that it is possible to overcome these difficulties if a better training in historiography, historical knowledge and studies on historical education is provided, and if this instruction is complemented with reflective teaching practices and theoretical foundations. It is not possible to teach what is not known. (99)

In accordance, Pagès (2009) and Levstik and Bartón (2001) indicate that one of the main challenges of the initial and permanent training of history teachers is to reconfigure the disciplinary approach and enrich the pedagogical and didactic components.

\section{METHOD}

\section{Collection of Data}

As mentioned in the introduction, three documents were selected for this paper: the training objectives of the social sciences field of study for primary and secondary education, the Curricular Standards, and the 2014 Saber Test history questions (Table 1). This was the only test to be included because it is the one whose questions have been made public. In spite of multiple requests made to the ICFES (Instituto Colombiano para el Fomento de la Educación Superior - Colombian Institute for the Promotion of Higher Education) to allow us to view the 2015, 2016 and 2017 tests, they have insisted that they are confidential, and that we can view sample questions published on their website. The results and instructions that the Ministry of Education (MEN) and the ICFES have published in 2014, 2015, and 2016 were also reviewed to help understand the results of the students and the ranking of the schools.

Table 1

Types of documents analyzed and Abilities for the development of historical thought that were analyzed

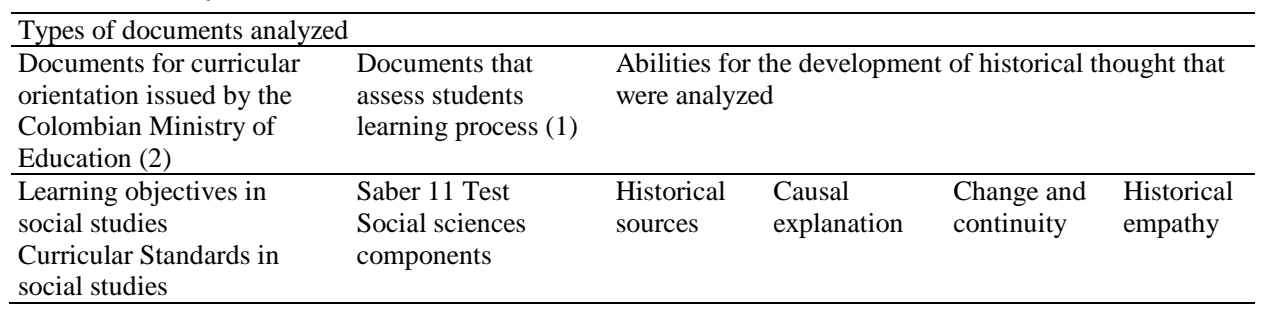

The selection criteria for these documents are the following: the first two (Training Objectives and Curricular Standards) contain the goals of teaching history for the primary and secondary levels; the third (Results of Students in the Saber Test) measures the levels of compliance with these teaching goals. 


\section{Data analysis}

The data were subjected to a content analysis with the following steps: First, the definition of analysis categories; second, the elaboration of documentary records; third, the classification by themes and coding of the categories identified in each of the documents reviewed. It was decided to use as categories for analysis an adaptation of Domínguez's (2015) historical thinking skills. (Figure 2)

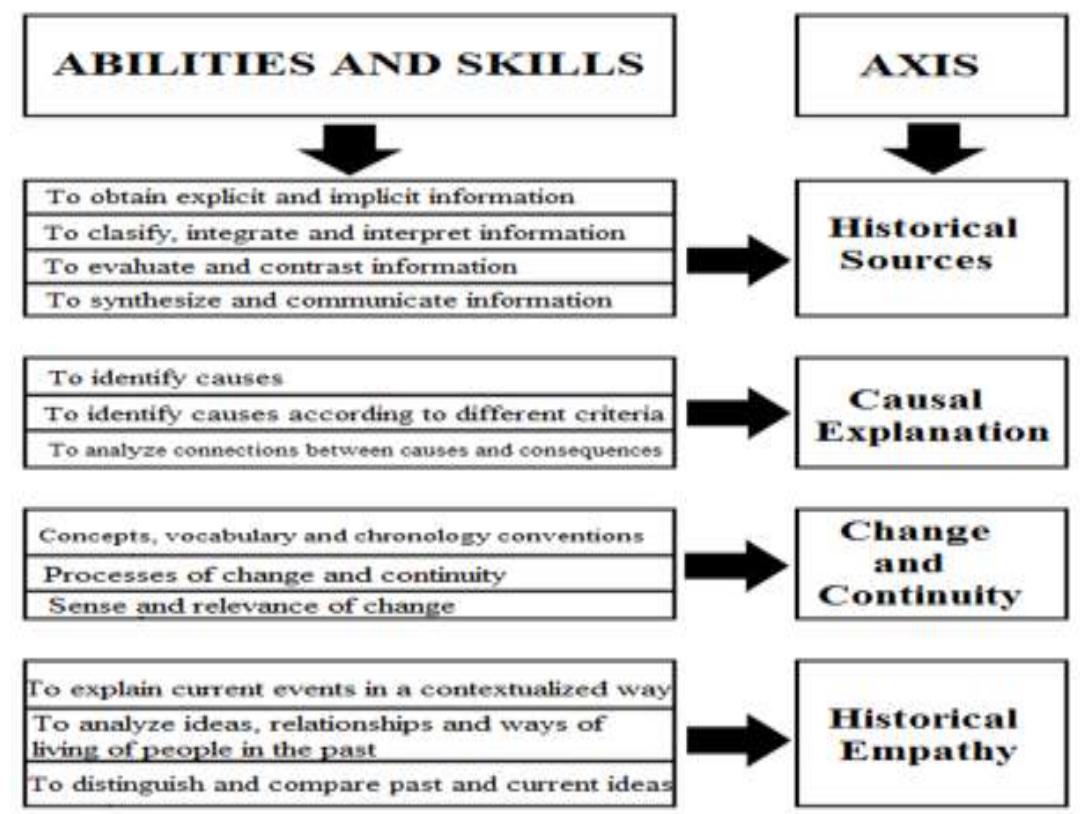

Figure 2

Abilities for the development of historical thought. Taken from: Domínguez (2015)

The existence of these skills was identified in the three analyzed documents. In the case of Curricular Standards, in addition to the identification, the number of times they appear was quantified. In the Saber 11 Test, in addition to Dominguez's development skills of historical thinking, the competences evaluated by the ICFES were identified, and the questions were classified, based on the model proposed by Villa (2007) and Monteagudo (2014).

\section{RESULTS}

\section{Historical Thinking and The Colombian Curriculum}

As mentioned before, with regard to the curriculum, two documents that are still in force in teaching social sciences were analyzed: the general objectives for primary and secondary education and the Curricular Standards for this field, which in Colombia, includes geography, history, Political Constitution and democracy. 


\section{General objectives of basic education:}

To promote knowledge and understanding of the national reality in order to consolidate the values of Colombian nationality such as solidarity, tolerance, democracy, justice, social coexistence, cooperation and mutual aid (Law 115, 1994, art. 20, lit. d.).

\section{Objectives of basic education in the primary cycle:}

To encourage the desire to learn, and to develop both a personal initiative towards knowledge and social reality, as well as a critical spirit (Law 115, 1994, art. 21, lit. b.).

Objectives of basic education in the secondary cycle:

To promote a scientific study of national and world history aimed at understanding the development of society, as well as the study of social sciences to encourage the analysis of current conditions of the social reality (Law 115, 1994, art. 22, lit. h.).

\section{Other objectives of the social sciences field:}

To incorporate research into the cognitive process, both in the laboratory as in the national reality in its natural, economic, political and social aspects (Law 115, 1994, art. 30, lit. c.).

An analysis of these objectives indicates that the intention of the Colombian State is not in conflict with the axes that guide the formation of historical thought today; on the contrary, they coincide significantly. The objectives include the concept of a "scientific" education, one that emanates from a rigorous teaching of history with epistemological and methodological bases. They also move away from the idea that anchors history as the teaching of the past and, on the contrary, recognize in it valuable instruments to understand the present. In addition, they imply the need to surpass an approach based on memorization of historical facts with a shift towards more complex cognitive actions that integrate conceptual, procedural, and attitudinal contents.

The second document analyzed was the Curricular Standards of Social Sciences published by the Ministry of Education in 2004. According to the Ministry, this document comprises the basic knowledge and skills that all children and teenagers in the country must acquire in primary and secondary education, regardless of the type of educational institution they attend, the region in which they live, and their socioeconomic or cultural status.

As can be seen in the Standards' structure (in an appendix attached to this text) knowledge of history appears mostly in the columns "Me aproximo al conocimiento como científico social" ("I approach knowledge as a social scientist") and in "Relaciones con la historia y las culturas" ("Relations with history and cultures"). To a lesser extent, it appears in the columns "Relaciones espaciales y ambientales" ("Spatial and environmental relations"), "Relaciones ético políticas" ("Ethical political relations") and "Desarrollo de compromisos personales y sociales" ("Development of personal and 
social commitments") $)^{4}$. In the analysis of each of the articulating axes from $1^{\text {st }}$ to $11^{\text {th }}$ grades, performance indicators related to the development of historical thought were identified and quantified by skills and grades.

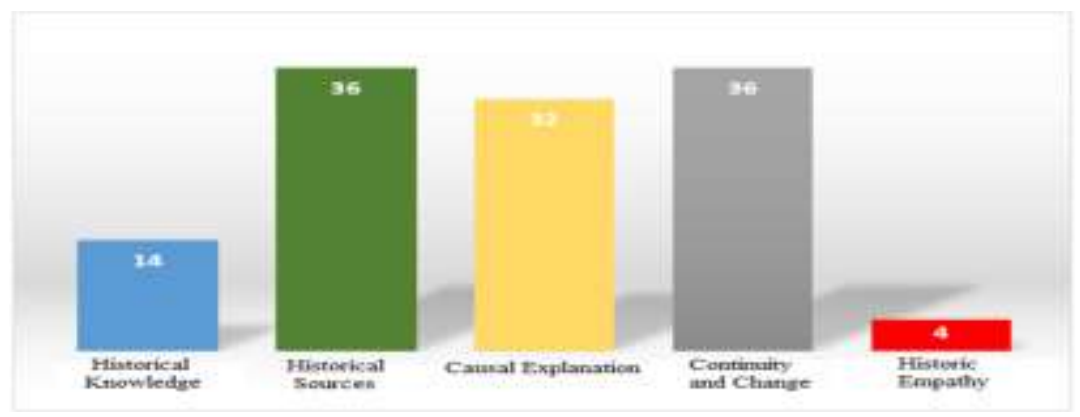

Figure 3

Historical thought skills in the standards of social sciences

Figure 3 indicates that the working skills in Historical Sources and in Change and Continuity had the greatest amount of performance indicators, with 36 each, followed by 32 in Causal Explanation. The axis with the least number was Historical Empathy, with 4. Those in Knowledge of History-acquired through basic actions or with a low level of complexity - had 14 indicators. This suggests that the Colombian curriculum has mainly incorporated axes of work to the development of historical thought, and at least in its objectives, it seeks to go beyond the traditional teaching of history.

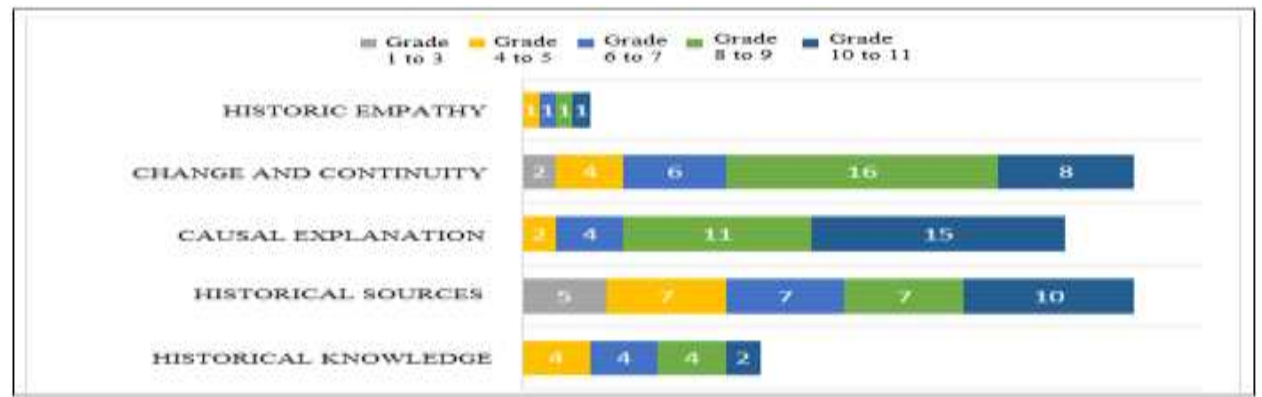

Figure 4

Historical thought abilities according to students' grade

Regarding the distribution of development skills of historical thinking by training cycles $^{5}$, as shown in Figure 4, the following was identified: In the $1^{\text {st }}$ to $3^{\text {rd }}$ cycle, there

\footnotetext{
${ }^{4}$ For a better illustration of the Curricular Standards of Social Sciences structure, the example for 4th and 5th grades in the primary school $\mathrm{g}$ was attached.

5 The Curricular Standards of Colombia contemplate the formation of primary and secondary education by cycles. Each cycle consists of two or three grades.
} 
are no performance indicators of the causal explanation ability; in the cycle from $4^{\text {th }}$ to $5^{\text {th, }}$ there are 2 ; in the $6^{\text {th }}$ to $7^{\text {th }}, 4$; in the $8^{\text {th }}$ to $9^{\text {th }}, 11$, and in the $10^{\text {th }}$ to $11^{\text {th }}, 15$.

In reference to the Ability of Change and Continuity, 2 performance indicators were quantified in the $1^{\text {st }}$ to $3^{\text {rd }}$ cycle, 4 in the $4^{\text {th }}$ to $5^{\text {th }}, 6$ in the $6^{\text {th }}$ to $7^{\text {th }}, 16$ in the $8^{\text {th }}$ to $9^{\text {th }}$, and 8 in the $10^{\text {th }}$ to $11^{\text {th }}$. The number of indicators in the last cycle decreased as a result of students beginning to do small research exercises that require the implementation of more complex skills such as identifying the meaning and relevance of historical changes in society.

Regarding the ability to work with Historical Sources, 5 performance indicators were identified in the $1^{\text {st }}$ to $3^{\text {rd }}$ cycle, 7 in the following three cycles, and 10 in the $10^{\text {th }}$ to $11^{\text {th }}$ cycle. A detailed analysis of the Curricular Standards for Social Sciences document allowed us to identify concrete examples of performance indicators in which historical thinking skills of low cognitive complexity are found. Two of the performance indicators of the $7^{\text {th }}$ to $8^{\text {th }}$ cycle are:

I identify some situations that have generated conflicts in social organizations.

I describe characteristics of the social, political or economic organization in some cultures and times.

The exemplified performance indicators have a low level of cognitive complexity, since students do not use methodological or second-order concepts. They are carried out through simple activities such as basic literal or inferential readings and very basic transcription, comparison and description exercises. 14 of these types of actions, traditionally used in teaching history, as illustrated in Figure 3, were identified in the Curriculum Standards for Social Sciences. Table 2 includes specific examples of performance indicators for each historical thinking skill. 
Table 2

Historical thinking skills in the social science curricular standards

\begin{tabular}{|c|c|}
\hline Performance Indicators & Historical Thought Skills \\
\hline \multicolumn{2}{|l|}{ Causal Explanation } \\
\hline $\begin{array}{l}\text { I identify some of the processes that caused the } \\
\text { modernization of Colombia during the XIX century and } \\
\text { the first half of the century (agricultural bonanza, } \\
\text { industrialization processes, urbanization) }\end{array}$ & To identify causes \\
\hline $\begin{array}{l}\text { I compare the causes of some migrant waves and human } \\
\text { displacement in our territory during the XIX century and } \\
\text { the first half of the century (colonization from some } \\
\text { regions, urbanization of the country). }\end{array}$ & $\begin{array}{l}\text { To classify causes according to } \\
\text { different criteria }\end{array}$ \\
\hline $\begin{array}{l}\text { I recognize multiple relations between historical events: } \\
\text { their causes, consequences and incidence over the lives of } \\
\text { agents and groups that were involved. }\end{array}$ & $\begin{array}{l}\text { To analyze connections between } \\
\text { causes and consequences }\end{array}$ \\
\hline \multicolumn{2}{|l|}{ Use of Historical Sources } \\
\hline $\begin{array}{l}\text { I collect and register the information that I obtain from } \\
\text { different sources. }\end{array}$ & $\begin{array}{l}\text { To obtain explicit and implicit } \\
\text { information. }\end{array}$ \\
\hline $\begin{array}{l}\text { I classify the sources that I use considering if they are } \\
\text { primary, secondary, oral, written iconographic or } \\
\text { statistics. }\end{array}$ & $\begin{array}{l}\text { To classify, integrate and interpret } \\
\text { information. }\end{array}$ \\
\hline $\begin{array}{l}\text { I stablish relations between information from different } \\
\text { sources and propose answers to the questions I find. }\end{array}$ & $\begin{array}{lll}\text { To evaluate and contrast } \\
\text { information. }\end{array}$ \\
\hline $\begin{array}{l}\text { I quote the different sources where I obtained information } \\
\text { adequately. }\end{array}$ & $\begin{array}{l}\text { To synthetize and communicate } \\
\text { information. }\end{array}$ \\
\hline \multicolumn{2}{|l|}{ Change and continuity } \\
\hline $\begin{array}{l}\text { I recognize that the division among historical periods is } \\
\text { an intend to characterize historical events determined by } \\
\text { important social transformations. }\end{array}$ & $\begin{array}{l}\text { Concepts, vocabulary } \\
\text { chronology conventions. }\end{array}$ \\
\hline $\begin{array}{l}\text { I identify and describe changes and aspects that remain } \\
\text { constant on myself and the organizations in which I } \\
\text { participate. }\end{array}$ & Processes of change and continuity. \\
\hline $\begin{array}{l}\text { I compare cultural legacies (scientific, technologic, } \\
\text { artistic and religious) from different cultural groups and I } \\
\text { recognize the impact that those characteristics have } \\
\text { nowadays. }\end{array}$ & Sense and relevance toward change. \\
\hline \multicolumn{2}{|l|}{ Historical empathy } \\
\hline $\begin{array}{l}\text { I identify the purposes of Spanish colonial organizations } \\
\text { and describe basic aspects of their functioning. }\end{array}$ & $\begin{array}{l}\text { To explain present events in a } \\
\text { contextualized way. }\end{array}$ \\
\hline $\begin{array}{l}\text { I recognize that social phenomena can be approached } \\
\text { from different viewpoints, perspectives and interests. }\end{array}$ & $\begin{array}{l}\text { To analyze ideas, relations and life } \\
\text { conditions of people from the past in } \\
\text { a contextualized way. }\end{array}$ \\
\hline I stablish relations between these cultures and their times. & $\begin{array}{l}\text { To distinguish and compare current } \\
\text { ideas with ideas from other times. }\end{array}$ \\
\hline
\end{tabular}

As shown in Table 2, the Causal Explanation skill performance indicators have three levels of complexity, in which, according to the Standards' outlook, the students must progress as they pass from one cycle to the next. The first example corresponds to the 
first level, in which students are expected to identify the causes of historical processes. The second example corresponds to the second level in which, in addition to identifying causes, they must classify them according to various criteria. In the third example, in addition to identifying and classifying them, students must determine connections between the causes and consequences of historical events and processes.

As for the indicators of Change and Continuity examples, students are expected to recognize transformations in near and distant environments, in aspects such as political and social organization, economic production and cultural expressions. The goal is to develop skills to determine the legacy of cultures to today's world, and to establish that at different times in history, men and women relate and exploit resources according to their needs.

It should be noted that the inclusion of vocabulary, concepts of change, continuity, and historical chronology in the examples, presumes that after having mastered them, the students can advance to more complex operations, which imply identifying them in the development of a historical process.

\section{Historical Thinking and Evaluation}

As mentioned, in Colombia, the teaching of social sciences in general, and of history, in particular, is evaluated in the Saber 11 Test. These tests have gained great importance in recent years, because in addition to reveal the scores to enter most universities in the country, their results are used as one of the indicators to classify schools, measure the quality of education in educational institutions, and grant scholarships and economic incentives to students, teachers, and school managers and administrators.

According to documents published by the MEN and the ICFES (2015a), a review, carried out by experts from both institutions, on current international assessments in social sciences (in which history is included), led to affirm that they seek to evaluate if students have the adequate thinking tools to understand interdependences and interconnections between historical events and social phenomena; if they use concepts when constructing social explanations; if they identify changes and permanence in the historical development of different phenomena; if they analyze the use of evidence when making interpretations; if they formulate conclusions based on evidence; if they examine consequences of decisions and actions; if they analyze the advantages and disadvantages of applying social theories, and if they compare different interpretations about the same event or phenomenon.

This review also led to the conclusion that it was necessary to include in the Colombian exam: the use of basic concepts in the different disciplines that comprise social sciences in order to understand and ponder on the social world; an understanding of spatial and temporal dimensions of events, phenomena, problems and social practices; a contextualization and evaluation of primary and secondary sources as fundamental tools for the construction of social thought; an understanding of the perspectives of different 
actors and social groups; a reflection and critical analysis on the uses of social sciences in social discourses and practices (ICFES and MEN 2016a, 8) ${ }^{6}$.

Table 3

Classification of history questions in the saber 11 test

\begin{tabular}{|c|c|c|c|c|}
\hline $\begin{array}{l}\text { Classification of } \\
\text { questions } \\
\text { according to the } \\
\text { required cognitive } \\
\text { capacity }^{7}\end{array}$ & $\begin{array}{l}\text { Content of the } \\
\text { Historical } \\
\text { question }\end{array}$ & $\begin{array}{l}\text { Knowledge about } \\
\text { history/required } \\
\text { knowledge about } \\
\text { history } \\
\text { (axes of the } \\
\text { development of } \\
\text { historical thinking) }\end{array}$ & $\begin{array}{l}\text { Competence } \\
\text { evaluated } \\
\text { according to } \\
\text { the } \\
\text { Colombian } \\
\text { standards }\end{array}$ & $\begin{array}{l}\text { Required ability in } \\
\text { the statement of the } \\
\text { question }\end{array}$ \\
\hline $\begin{array}{l}\text { Comprehension of } \\
\text { facts }\end{array}$ & $\begin{array}{l}\text { Industrial } \\
\text { Revolution }\end{array}$ & Causal explanation & Social thought & $\begin{array}{l}\text { It can be affirmed that } \\
\text { one of the } \\
\text { consequences of this } \\
\text { revolution, regarding } \\
\text { the population was... }\end{array}$ \\
\hline $\begin{array}{l}\text { Comprehension of } \\
\text { concepts }\end{array}$ & $\begin{array}{l}\text { Economic crisis } \\
\text { of } 1929\end{array}$ & $\begin{array}{l}\text { Knowledge about } \\
\text { history }\end{array}$ & Social thought & $\begin{array}{l}\text { To counteract the } \\
\text { effect of this crisis, } \\
\text { Latin American States } \\
\text { adopted measures } \\
\text { such as import } \\
\text { substitution that } \\
\text { consisted of... }\end{array}$ \\
\hline $\begin{array}{l}\text { Comprehension of } \\
\text { concepts }\end{array}$ & Socialism & $\begin{array}{l}\text { Knowledge about } \\
\text { history }\end{array}$ & $\begin{array}{l}\text { Historic and } \\
\text { reflexive } \\
\text { thought }\end{array}$ & $\begin{array}{l}\text { Socialism seeks } \\
\text { social, politic and } \\
\text { economic equality. To } \\
\text { achieve that purpose, } \\
\text { socialism proposes } \\
\text { to... }\end{array}$ \\
\hline Appraisal of facts & $\begin{array}{l}\text { The Arab- } \\
\text { Israeli conflict }\end{array}$ & Historical empathy & Social thought & $\begin{array}{l}\text { Palestine is not } \\
\text { recognized as a State } \\
\text { because... }\end{array}$ \\
\hline $\begin{array}{l}\text { Recollection of a } \\
\text { fact }\end{array}$ & National Front & Knowledge of history & $\begin{array}{l}\text { Interpretation } \\
\text { and analysis } \\
\text { of } \\
\text { perspectives }\end{array}$ & $\begin{array}{l}\text { With which period of } \\
\text { the politic history of } \\
\text { Colombia is this } \\
\text { discourse related? }\end{array}$ \\
\hline $\begin{array}{l}\text { Application or } \\
\text { usage of a concept }\end{array}$ & $\begin{array}{l}\text { Economic } \\
\text { liberalism }\end{array}$ & $\begin{array}{l}\text { Knowledge about } \\
\text { history }\end{array}$ & $\begin{array}{l}\text { Systemic and } \\
\text { reflexive } \\
\text { thought }\end{array}$ & $\begin{array}{l}\text { Which of the } \\
\text { following situations } \\
\text { agree with the } \\
\text { previous statement? }\end{array}$ \\
\hline
\end{tabular}

The classification of the questions in Table 3, was based on the model proposed by Villa (2007) and

\footnotetext{
${ }^{6}$ After having taken into account the above and identified the elements that are essential to evaluate the Saber 11 Test in social sciences and civic engagement competences, the evaluation of the following was proposed: social thinking, interpretation, perspective analysis, systemic and reflexive thinking (ICFES and MEN, 2016a, 16).

7 The classification of the questions was developed based on the model proposed by Villa (2007) and Monteagudo (2014). The axes of development of historical thinking were adapted from Domínguez (2015). The competences and the questions in the tests were taken from the exam applied in 2014-II, and for the guidelines for the interpretation of their results published by Icfes and MEN (2015 y 2016a).
} 
Monteagudo (2014). The axes of development of historical thinking were taken from Domínguez (2015). The competences and questions of the Test were taken from the exam applied in 2014-II, and from the guidelines for the interpretation of its results published by the ICFES and the MEN (2015 and 2016a).

The classification of the questions table 3, was based on the model proposed by Villa (2007) and Monteagudo (2014). The axes of development of historical thought were taken from Domínguez (2015). The competences and questions of the Test were taken from the exam applied in 2014-II, and from the guidelines for the interpretation of its results published by the ICFES and the MEN (2015 and 2016a).

An analysis of the students' evaluation allow us to infer that the knowledge of history, as taught in a traditional way, and about history and axes of the development of historical thought do not conflict neither with the articulating axes of the Curricular Standards defined by the MEN, nor with the competences defined by both the MEN and the ICFES to be evaluated in the Saber 11 Test. On the contrary, they coincide in the knowledge and skills that the students must have.

Below, we present the history questions of the Saber 11 Test, analyzed in this article. These questions illustrate not only the evaluation approach to the development of historical thought, but also some of the topics that are being evaluated.

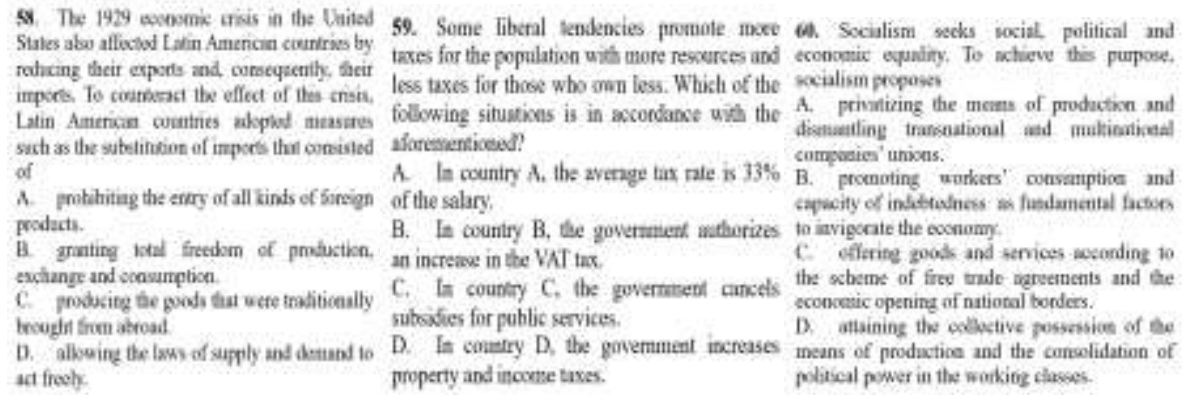

History questions from the Saber 11 Test. Source: ICFES (2015)

While the three questions require students to understand concepts and apply and remember facts, the skills required are very basic in that the students are asked to show what they know and what they remember (socialism, import substitution, economic liberalism). However, this does not involve methodological procedures that lead them to express their knowledge in some of the axes of the development of historical thought.
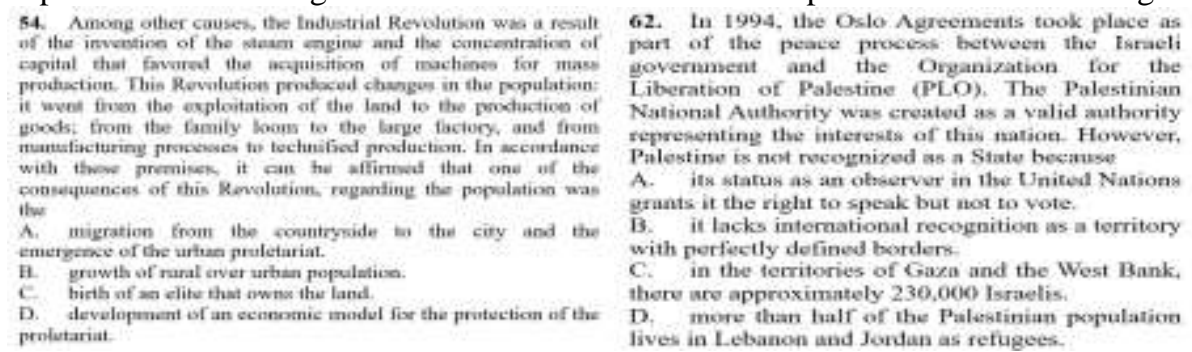

History questions from the Saber 11 Test. Source: ICFES (2015) 
Questions about the Industrial Revolution and the Arab-Israeli conflict have a higher level of complexity since they evaluate the understanding of facts and the assessment that students make of them. These questions involve methodological procedures such as the identification of consequences and the motivations of a certain action.

\section{Open Question}

Answer the following question in your answer sheet, with neat handwriting and in the space provided for this purpose.

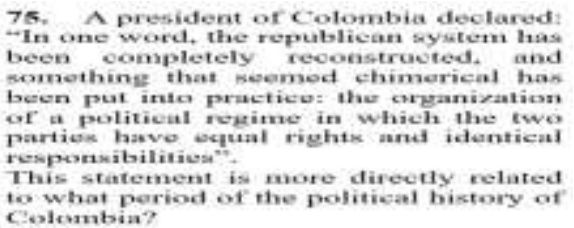

History question from the Saber 11 Test. Source: ICFES (2015)

The only open question in the exam generates concern because the students have very limited space to answer it. If they go beyond that space, the answer is cancelled. The space restriction (a couple of lines) prevents the student from writing a paragraph, a narrative, or a text that would undoubtedly enable a better evaluation of his/her level of development of historical thinking.

The six questions that explicitly involve knowledge of history, which correspond to $24 \%$ of the 25 social science questions in the test, are proof that the test is very basic. It is interesting to note that although the curriculum has advanced in terms of seeking a more complex learning, this evaluation does not keep pace with it. However, we must clarify that the test used in this article dates from 2014, since the ones from 2015, 2016 or 2017 cannot be accessed for the reasons mentioned before.

It is disturbing that even with basic level questions, the results in the field of social sciences have not improved. The averages for the 2014, 2015, and 2016 Saber Tests show little progression in learning this discipline. During this period, the average only rose from 50 to 51 .

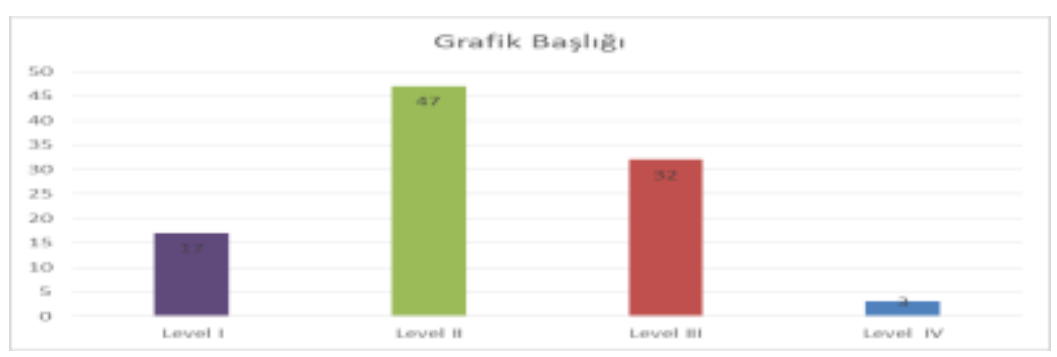

Figure 5

Averages of the test according to development levels 
Regarding the distribution of students by performance levels, the social science and civic engagement test results (Figure 5) indicate that $64 \%$ of the students are classified in the basic levels I and II, in which they only perform very simple operations such as transcribing information but not complex cognitive ones. $32 \%$ of the students are in level III, having made progress in learning and in making more complex cognitive operations. Finally, only $3 \%$ are at a desirable level, having acquired the necessary knowledge to enroll in a university.

\section{DISCUSSION AND CONCLUSIONS}

Many controversies have arisen throughout the country because the General Law of Education, which defines the objectives of training by cycles, established "geography, history, the Political Constitution and democracy" as part of the social sciences field of study. For authors like Montenegro (1999), Sánchez (2013), and Arias (2015), not only did the confusion about the contents of social sciences increase, but under this designation, the law organized a compilation of disjointed subjects with no hierarchy, making the disciplinary postulates disappear for the sake of a supposed interdisciplinary learning; also, teaching time was significantly reduced in two to four hours per week, depending on the institution.

According to Arias (2015), what hinders teaching social sciences in Colombia is the application of the national tests, the Saber Tests. As mentioned before, these have been one of the indicators to measure the quality of education. Based on their results, institutions are classified, and scholarships, economic and symbolic incentives (diplomas and medals) are awarded to students and teachers.For Arias (2015), the logic of the exams is raised as a new intermediary, that together with the faculties of Education and the institutions' educational communities determine to a large extent what is taught in the classrooms. From his perspective, the documents that determined the type of test given, define social sciences as sciences of understanding, whose character is hermeneutic and are said to include the new global educational trends.

In practice, the logic of the ICFES exams marked the development of the curricula in educational institutions and the structure of textbooks in this field. In essence, by prescribing the logic of the creation of standardized tests, the performance of schools and their classification are measured according to a ranking of quality. Beyond epistemological discussions about the nature of school discipline in the social imaginary and educational policies, the results of these evaluations will define the quality of education in the country (Arias 2015, 140).

The objectives of teaching social sciences and the Curricular Standards of this discipline show that, in Colombia, as in other Latin American countries, there is a clear intention to transcend "the nineteenth-century teaching of history in which the invention of a national identity, warlike conflicts and the consolidation of a patriotic pantheon predominated" (Plá 2010, 72).

All the documents reviewed express the need for students to understand how scientists proceed, how they obtain their data, construct their explanations and originate their reflections and contributions. It also aims for students to recognize the key aspects of 
scientific research (OECD 2013). In the specific case of social sciences and history, students are expected to understand how geographers or historians proceed, how they obtain their sources, the treatment they give them, and how they generate hypotheses and conclusions.

However, the data in Table 2 and Figure 3 indicate that this decision to change, so clearly defined in the goals and learning objectives set by the State, has not been reflected in the evaluations that still have a low cognitive level, nor in the classrooms; the results show that not even in those basic levels of learning has significant progress been made. We do not intend to suggest that the inclusion of a curricular document leads to automatic improvements in education, because there are other significant factors, such as the work performed by teachers. What we want to highlight is that the objectives of the published Curricular documents have not been fulfilled, precisely because only a minority of students has reached the levels of learning proposed as desirable for all.

A better understanding of the social world and its problems could be achieved if historical development skills with high cognitive, procedural and attitudinal levels could be integrated to the design of learning activities and evaluations. Developing competences of and about history is a fundamental step to achieve a critical and rational approach to their daily lives, for which a better historical literacy is more than necessary (Pagès 2009, Sáiz and López 2012).

For Domínguez (2015), despite the constant allusion to educational competences, in reality, the vast majority of teachers perceive these as another term in the already overburdened educational jargon, which will also be unable to modify the contents and traditional teaching habits. As Cuesta (1998) emphasizes, it is urgent to transcend school routines derived from traditional textbooks and manuals, to broaden the use of curricular materials of didactic innovation in history with adequate and ascending cognitive levels, to create materials through a flexible use of the textbook, and to introduce work plans or alternative didactic sequences.

On the other hand, it is important to note that the influence that performance indicators have on the use of historical sources in the Curricular Standards (36), is not reflected in the Saber 11 Test questions. Only one of the history questions includes a fragment of a speech by a Colombian president, and the question posed to the students is not about the content of the speech but about the time in which it occurs.

The development of skills such as the construction of historical discourses, causality, changes and permanence in society from a multifactorial perspective, historical awareness, and the approach to historical problems are cognitive skills that require specific teaching techniques and procedures (Gómez and Miralles 2015, 64).

In addition to the concern about the low cognitive complexity of the evaluation, we must raise questions about the effectiveness of this type of exam to evaluate some of the historical thinking skills. As indicated by Monteagudo, Villa and Miralles (2015), the introduction of competences has resulted in a rethinking of the evaluation that takes into account concepts, procedures and attitudes, and the use of new assessment instruments. 
Essays and multiple-choice questions, with different point values assigned to them, have also been proposed as evaluation instruments to determine if the student has the complex skills related to historical thinking (Trepat 20102 and VanSledright 2014).

Consequently, the major aspirations in the development of thought described in the objectives of training in history and in the Curricular Standards of social sciences in Colombia, do not comply with the Saber Test for this field. As this article is concerned with the teaching of history, we must say that, as Gómez and Miralles (2015) point out for Spain, there is evidence that we need to have additional and more varied instruments of evaluation that capture the students' diverse capacities to interpret the past and develop competences. The analysis of the questions confirms the need to include issues and exercises that require more complex cognitive skills from the students. For authors like Sáiz (2013), Lee and Shemilt (2004), the tests that measure the development of historical thought should include, in addition to multiple-choice questions, other types of questions involving an analytical review of sources to obtain evidence, construction of oral stories, and reasoned explanations and narratives in order to determine the levels of learning in terms of causal relationship, creation of simple and complex causal chains, and contextualized inferential knowledge.

\section{REFERENCES}

Arias, D. (2015). La enseñanza de las ciencias sociales en Colombia: lugarde las disciplinas y disputa por la hegemonía de un saber. Revista de Estudios Sociales, 52, $134-146$.

Barca, I. (2011). La evaluación de los aprendizajes en historia. En P.

Miralles., S. Molina y A. Santisteban (Eds), La evaluación y el proceso de enseñanza y aprendizaje de las ciencias sociales (pp.107-120). Murcia: Asociación Universitaria de Profesores de Didáctica de las Ciencias Sociales.

Barton, K. \& Linda L. (2004). Teaching History for the Common Good. Mahwah: Lawrence Erlbaum Associates.

Carretero, M. (2007). Documentos de identidad. La construcción de la memoria histórica en un mundo global. Buenos Aires: Paidós.

Carretero, M. \& López, C. (2009). Estudios cognitivos sobre el conocimiento histórico: aportaciones para la enseñanza y la alfabetización histórica. Revista Enseñanza de las Ciencias Sociales, 9, 79-83.

Carretero, M., López, C., González, M. \& Rodríguez-Moneo. (2012). Students Historical Narratives and Concepts about Nation. En M. Carretero., M. Asensio \& M. Rodríguez -Moneo (Eds), History Education and the Construction of National Identities (pp.153-170). Charlotte: Information Age Publishing.

Clark, P. (2011). New Possibilities for the Past. Shaping History Education in Canada. Vancouver-Toronto: UBC Press. 
Cooper, H. \& Capita, L. (2004). Leçons d'histoire à l'école primaire : comparaisons. Revue Le Cartable de Clio, 3, 155-168.

Cuesta, R. (1998). Clío en las aulas. La enseñanza de la historia de España: entre reformas, rutinas e ilusiones. Madrid: Akal.

Domínguez, J. (2015). Pensamiento Histórico y Evaluación de Competencias. Barcelona : Editorial GRAÓ.

Éthier, M., Demers S. \& Lefrançois D. (2010). Las investigaciones en didáctica sobre el desarrollo del pensamiento histórico en la enseñanza primaria. Una panorámica de la literatura publicada en francés e inglés desde el año 1990. Revista Enseñanza de las Ciencias Sociales, 9, 61-74.

Fuster, C. (2015). ¿Se evalúa el pensamiento histórico de los alumnos de $2^{\circ}$ Bachillerato? Análisis de la prueba de Historia de España de acceso a la Universidad. En L. Alves (Presidencia), XVI Congreso Internacional das jornadas de educaçao histórica. Epistemologias e ensino de história. Faculdade de Letras da Univerisdade do Porto.

Fuster, C. (2017). ¿Estamos preparados para evaluar el conocimiento histórico? Revista GeocritiQ, 278, 1-5

Gómez, C. \& Miralles, P. (2014). ¿Pensar históricamente o memorizar el pasado? La evaluación de los contenidos históricos en la educación obligatoria en España. Revista de Estudios Sociales, 52, 52-58.

Gómez, C., Ortuño, J. \& Molina, S. (2014). Aprender a pensar históricamente. Retos para la historia en el siglo XXI. Revista Tempo e Argumento, 6(11), 5-27.

Gómez, C., Miralles, P., \& Molina, S. (2014). Evaluación, competencia histórica y educación ciudadana. Revista de Estudios Sociales, 52, 9-14.

Granata, M. \& Barale, C. (2001). Problemas epistemológicos en el conocimiento social e histórico. Fundamentos en Humanidades, 3, 59-77.

Instituto Colombiano para la Evaluación de la Educación y Ministerio de Educación Nacional. (2015). Cuadernillo de aplicación de la Prueba Saber 112014 B. Bogotá.

Instituto Colombiano para la Evaluación de la Educación y Ministerio de Educación Nacional. (2016 ). Guía de interpretación y uso de resultados de las Pruebas Saber 11. Establecimientos educativos. Bogotá.

Instituto Colombiano para la Evaluación de la Educación y Ministerio de Educación Nacional. (2016b). Reporte de resultados del examen Saber 11 por aplicación 2016 -2. Establecimientos Educativos. Bogotá.

Instituto Colombiano para la Evaluación de la Educación y Ministerio de Educación Nacional. (2017). Informe nacional 2014 - II- 2016- II. Bogotá. 
Lee, P. \& Ashby, R. (2000). Progression in Historical Understanding among Students Ages 7-14. In P. Stearns., P. Seixas. \& S. Wineberg (Eds), Knowing Teaching and Learning History (pp. 199-222). New York, New York: University Press

Lee, P. \& Shemilt, D. (2004). "I just wish we could go back in the past and find out what really happened". Progression in understanding about historical accounts. Journal Teaching History, 117, 25-31.

Lee, P. (2005). Historical Literacy: Theory and Research. International Journal of Historical Learning, Teaching and Research, 5(1), 29-40.

Lévesque, S. (2008). Thinking Historically. Educating Students for the 21st Century. Toronto: University of Toronto Press.

Levstik, L., \& Barton, K. (2001). Doing History. Investigating with Children in Elementary and Middle Schools. New Jersey: Lawrence Erlbaum Associates (LEA)

López, R., Velasco, L., Santidrián V., \& Armas X. (2011). Pensar históricamente en tiempos de globalización. Santiago de Compostela: Universidad de Santiago de Compostela.

Martineau, R. (1999) L'histoire à l'école, matière à penser. Paris : L'Harmattan.

Ministerio de Educación Nacional. (1994). Ley 115 o Ley General de Educación. Bogotá.

Ministerio de Educación Nacional. (2004). Estándares Básicos de Ciencias Sociales. Bogotá.

Morín, E. (2001). Los siete saberes necesarios para la educación del futuro. Barcelona: Paidós Studio.

Monteagudo, J. (2014). "Las prácticas de evaluación en la materia de Historia de 4. de ESO en la Comunidad Autónoma de la Región de Murcia”. Disertación doctoral. Universidad de Murcia, España.

Monteagudo, J., Villa, J \& Miralles, P. (2015). Las Prácticas de evaluación en las materias de ciencias sociales de ESO en la Región de Murcia según la opinión de los inspectores de educación. Revista Didácticas de las ciencias experimentales y sociales, 29, 61-88.

Montenegro, A. (1999). Convergencias y divergencias entre la creación del conocimiento histórico y su enseñanza en Colombia durante el siglo XX. Revista Historia de la Educación Colombiana, 2, 131-149.

OECD. (2013). Assessment and Analytical Framework. Mathematics, Reading, Science, Problem Solving and Financial Literacy. Retrieved from: <www.oecd.org/pisa/pisaproducts/PISA\%202012\%20framework\%20e-ook_final.pdf>

Osborne, K. (2003). Teaching History in Schools: A Canadian Debate. Journal of Curriculum Studies, 35(5), 585-626. 
Pagès, J. (2009). El desarrollo del pensamiento histórico como requisito para la formación democrática. Revista Reseñas de Enseñanza de la historia, 7, 69-91.

Plá, S. (2005). Aprender a pensar históricamente. La escritura de la historia en el bachillerato. México: Plaza y Valdés.

Plá, S. \& Pérez, M. (2013). Pensar históricamente sobre el pasado reciente de México. Revista Clio \& Asociados, 17, 27-55.

Plá, S. (2013). Ciudadanía y competitividad en la enseñanza de la historia. Los casos de México, Argentina y Uruguay. México D.F.: Universidad Iberoamericana.

Plá, S. (2010). Las competencias: Eje para la transformación del conocimiento histórico escolar. Un estudio comparativo en América Latina. Revista enseñanza de las ciencias sociales, 10, 65-72.

Prats, J. \& Santacana, J. (2011). ¿Por qué y para qué enseñar historia? En Didáctica de la Geografía y la Historia, coord. Joaquim Prats. Barcelona: Graó.

Pontecorvo, C. \& Girardet H. (1993). Arguing and Reasoning in understanding historical topics. Journal Cognition and Instruction, 11 (3 \& 4), 365-395.

Pousa, M. \& López R. (2013). Eurocentric History in Spanish Textbooks. International. Journal of Historical Learning, Teaching and Research, 12(1), 107-120.

Rüsen, J. (2007). "Memory, History and the Quest for the Future". In L. Cajani (Ed.), History Teaching, Identities and Citizenship. European Issues in Children's Identity and Citizenship (pp. 13-54). Stoke on Trent: Trentham Books.

Sáiz, J. (2013). Alfabetización histórica y competencias básicas en libros de texto de historia y en aprendizaje de los estudiantes. Revista Didáctica de las Ciencias Experimentales y Sociales, 27, 43-66.

Sáiz, J. \& López R. (2012). Aprender y argumentar España. La visión de la identidad española entre el alumnado al finalizar el bachillerato. Revista didácticas de las ciencias experimentales y sociales, 26, 95-120.

Sáiz, J., \& López, R. (2014). Competencias y narrativas históricas: el pensamiento histórico de estudiantes y futuros profesores españoles de educación secundaria. Revista de Estudios Sociales, 52, 87-101.

Sáiz, J. \& Gómez, C. (2016). Investigar el pensamiento histórico y narrativo en la formación del profesorado: Fundamentos teóricos y metodológicos. Revista electrónica de formación del profesorado, 19 (1), 175- 190.

Santisteban, A. (2010). La formación de competencias de pensamiento histórico. Revista Clío \& Asociados, 14, 34-56.

Santisteban, A., González, N. \& Pagès, J. (2010). Una investigación sobre

la formación del pensamiento histórico. En R. Ávila., M. Riverio \& P. Domínguez (coordinación), XXI Simposio internacional de Didáctica de las Ciencias Sociales. 
Metodología de investigación en didáctica de las ciencias sociales, España: Universidad Autónoma de Barcelona.

Sánchez, N. (2013). Debates y discursos en torno a las ciencias sociales escolares entre 1984 y 2010 en Colombia. Revista Uni-pluri/versidad, 13, 69-80.

Seixas, P. (2011). Assessment of Historical Thinking. En P. Clark (Ed), New Possibilities for the Past. Shaping History Education in Canada (pp.139, 153). Vancouver - Toronto: University of British Columbia Press.

Seixas, P. \& Morton T. (2013). The Big Six Historical Thinking Concepts. Toronto: Nelson College Indigenous.

Souto, X. (2011). Las PAU de geografía; ¿un obstáculo o una oportunidad? En P. Miralles., S. Molina \& A. Santisteban (Eds.), La Evaluación en el proceso de enseñanza y aprendizaje de las ciencias sociales (pp.271 - 284). Murcia: Asociación Universitaria de Profesores de Didáctica de las Ciencias Sociales

Stearns, P., Seixas P. \& Wineburg S. (2000). Knowing, Teaching and Learning History. National and International Perspectives. New York, London: New York University Press.

Stearns, P. (2011). Childhood in World History Themes in World History. New York: Routledge

Trigueros, F., Ortuño J. \& Molina, S. (2014). La percepción del alumnado de educación secundaria sobre el desarrollo del pensamiento histórico en el proceso evaluador. Revista de Estudios Sociales, 52, 69-86.

Trepat, C. (2012). La evaluación de los aprendizajes de historia y geografía en la enseñanza secundaria. Las pruebas de ensayo abierto. Íber. Didáctica de las Ciencias Sociales, Geografía e Historia, 70, 87-97.

VanSledright, B. (2004). What does it mean to think historically? Journal of Social Education, 68(3), 230-233.

VanSledright, B. \& Limon, M. (2006). Learning and teaching in social studies: Cognitive research on history and geography. In P. Alexander \& P. Winne (Eds), The Handbook of Educational Psychology (pp.545-570). Mahweh: Lawrence Erlbaum Associates.

VanSledright, B. (2011). The Challenge of Rethinking History Education. On Practice, Theories, and Policy. New York: Routledge.

VanSledright, Bruce. (2014a). Assessing Historical Thinking and Understanding. Innovation Design for New Standards. New York: Routledge.

VanSledright, B. (2014b). Changing Epistemic Beliefs? An Exploratory Study of Cognition Among Prospective History Teachers. Journal Tempo e Argumento, 6(11), 28-68. 
Villa, J. (2007). Contextos para el aprendizaje: papel de las estrategias instruccionales $y$ de evaluación en el desarrollo de capacidades a partir del aprendizaje de la geografía. Madrid: Universidad Autónoma.

Wineburg, S. (2001). Historical Thinking and Other Unnatural Acts: Charting the Future of Teaching the Past. Philadelphia: Temple University Press.

Wineburg, S. (2007). Unnatural and essential: The nature of historical thinking. Journal of Teaching History, 129, 6-12. 